\title{
可変マッハ数ノズルをもちいたスクラムジェット 空力試験*1 Aerodynamic Tests of Scramjet Engines with Variable Mach Number Nozzle
}

\author{
北村 英二郎 ${ }^{* 2} \cdot$ 三 谷 徹*3 $\cdot$ 渡 邊 修 - ${ }^{* 4} \cdot$ 櫻 中 登*3 $^{* 3}$ \\ Eijiro Kitamura, Tohru Mitani, Syuichi Watanabe, Noboru Sakuranaka, \\ 高 橋 政 浩*3 · 升 谷 五 郎 ${ }^{* 5}$ \\ Masahiro TAKAHASHI and Goro MASUYA
}

Key Words : Supersonic Nozzle, Scramjet Engine, Aerodynamic Test

\begin{abstract}
A simple variable Mach number nozzle for aerodynamic engine tests was designed and calibrated. In this new nozzle, only one hydraulic actuator made freestream Mach number change from 2 to 4 during a run of the wind tunnel. The optimization of the nozzle contours was conducted by the 2-D computational simulation. The CFD results predicted that the deviation of Mach number from the averaged value was less than $1 \%$ and flow angle was less than 1 degree in the test region. The results of the calibration tests of the nozzle showed that the deviations of Mach number distributions in the test core $(60 \mathrm{~mm} \times 60 \mathrm{~mm})$ were less than $1.5 \%$ from Mach 2 to 3.5 and $3.5 \%$ at Mach 4 . This result assured that this nozzle was suitable for aerodynamic engine tests. The aerodynamic tests of scramjet engine models in acceleration/deceleration conditions were carried out with this nozzle. Air capture ratio and internal drag were measured. When freestream Mach number decreased, the soft unstart in the inlet was observed around Mach 3. It resulted in increase of the internal drags.
\end{abstract}

\section{1. は じめに}

次世代宇宙往還機であるスペースプレーンの推進システ ムとしてスクラムジェットエンジンが研究されており，これ までマッハ 4 から 8 までの飛行条件下で正味推力の発生が 実証されている11).このエンジンでは可変部を極力減らす 必要があり, 弚のため広いマッ八数のエンジン性能を調べ, エンジン内部形状を最適化する必要がある.特に低マッハ 数ではインレットの始動性やエンジン抗力などの空力特性 が問題となり，これらの空力特性を効率良く調べることが できる設備が必要となる.

乥こで本研究では低マッ八数における機体加速時のエン ジン空力特性を調べるために, 実験中に気流マッハ数をマッ 八 2 から 4 まで自由に変化できる自由噴流型風洞用の二次 元ノズルを設計・製作した . 通常の可変マッ八数ノズルで は,多数のアクチュエータによって可撓板を弾性変形させる ことにより気流マッハ数を変化させている。例えばJAXA 調布にある $1 \mathrm{~m}$ 正方形出口断面をもつ超音速風洞では, 11 対の油圧アクチュエータによって可撓板を変形させ , M1.4 から M 4.5 までマッ八数を変化させることができる ${ }^{2 \sim 4)}$.こ

\footnotetext{
*1 (C) 2005 日本航空宇宙学会

平成 16 年 10 月 25 日原稿受理

$* 2$ 東北大学大学院

*3 宇宙航空研究開発機構・角田宇宙推進技術センタ

$* 4$ 航空宇宙技術振興財団

$* 5$ 東北大学大学院工学研究科
}

のような形式のノズルは各マッハ数においてノズルコンタ を最適な形状にできるので，マッ八数分布や偏角が少ない 気流を得ることができる，光の反面，構造が大型でかつ複 雑になる．

弚こで本研究で製作したノズルでは，1枚の固定コンタ 壁をノズル出口端を中心に回転させ, 気流マッハ数を変化 させた .これにより稼動部を 1 つにすることができ，従来 の可変マッハ数ノズルに比べて構造を小型でかつ簡便にす ることができた .

本報告では最初にこのノズルの設計方法と較正試験の結 果について述べ, 既存ノズルの結果との比較を通して, こ のノズルがエンジンの空力試験に使用するのに十分な性能 があることを示す．次にこのノズルをもちいて側板圧縮型 インレットをもつスクラムジェットエンジンの空力試験を おこなった . 光して気流マッハ数が変化したときの壁圧分 布，エンジン抗カやインレット空気捕獲率を計測し，イン レットが不始動に移行する際の空力特性の变化を調べたの で報告する．なお記号表は文末にまとめた .

\section{2. 可変マッハ数ノズルの設計}

2.1 可変マッハ数ノズル 本研究で設計・製作した可変 マッハ数ノズルの写真を第 1 图に示す . 図の左側が亜音速 部で右側が超音速部である .このノズルでは固定コンタの 下壁を，下流端を中心に回転させスロート高さを変えるこ とによって，気流マッ八数を M2 から M4 まで試験中に自 


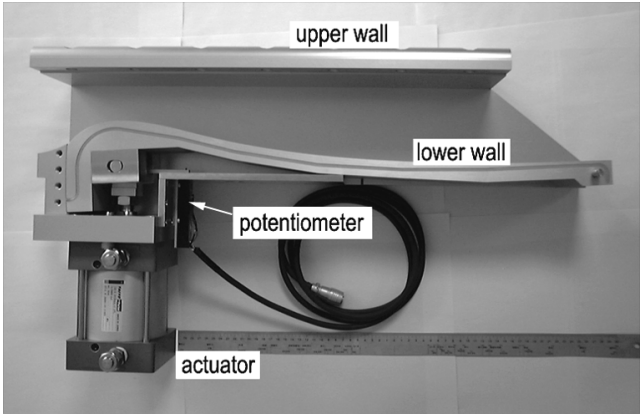

第 1 図 可変マッハ数ノズル

由に変えられる.出口断面は $100 \mathrm{~mm}$ 角の正方形 , ノズル 全長は $790 \mathrm{~mm}$ である . 超音速部は $600 \mathrm{~mm}$ ，亜音速部は $190 \mathrm{~mm}$ である .写真右下には，下壁を動かしてスロート高 さを変えるための油圧アクチュエータ (最大出力 $5500 \mathrm{~N}$ ) と, 光の変位量を測るためのポテンショメータが見える.

このノズルを使ってスクラムジェットェンジンの空力試 験をおこなう場合は，模型先端を上壁と同じ高さにあわせ て取り付ける，弚うして上壁で発達する境界層をエンジン 内に流入させ，実機で機体表面に発達する境界層がエンジ ンに取り込まれるのを模擬する.このようにエンジンをノ ズル出口に取り付けるために, ノズル気流が適正膨張のと き以外は下壁端から衝撃波もしくは膨張波が発生し，これ らがエンジン内に入射して内部流を乱す恐れがある．

乥こでノズル出口では上壁の方が下壁に比べて $120 \mathrm{~mm}$ 短くしている .これによって長さ $200 \mathrm{~mm}$ のインレットを もつ模型を取り付けた場合でも，下壁端からの波がインレッ 卜内部に入射しないようにした .ただしあまり上壁を短く しすぎると，模型前縁で発生した衝撃波か下壁コンタ上で 反射してインレットに入射し，かえって試験可能範囲を狭 めることになるので注意が必要である。例えば主流に対し て 8 度傾いたインレット ${ }^{5)}$ 前縁からの衝撃波は, ノズル出 口より $130 \mathrm{~mm}$ 下流で下壁に入射する．

2.2 基準コンタの設計 上述したように製作したノズ ルは固定コンタを回転させることにより気流マッハ数を変 化させる．乥こでより質の高い気流を得るために，特性曲 線法6) と数値計算を併用し，コンタの最適化をおこなった . なお本研究では, 既存の M 3.5 固定マッ八数ノズルの実験 データとも比較できるように，M2.5 から M 3.5 までの範囲 で最適化をおこなった .

まず特性曲線法をもちいて，あるマッハ数で完全波消し になるような形状を求めた 、次に特性曲線法で求めたコン 夕壁の座標を, スロート高さを変えるために出口端を中心 に回転させた .この回転させた形状について，数値計算を おこないノズル内部流を計算した .こうして数値計算によっ て，境界層の排除効果や，コンタ壁が回転した時の出ロマッ 八数分布や偏角の変化を調べた。

ノズル内部流計算は二次元時間平均ナビェ・ストークス 方程式を基礎方程式とするコードでおこなった . 流束の計 算には AUSM-DV 法7)を，時間積分には LU-SGS 陰解法

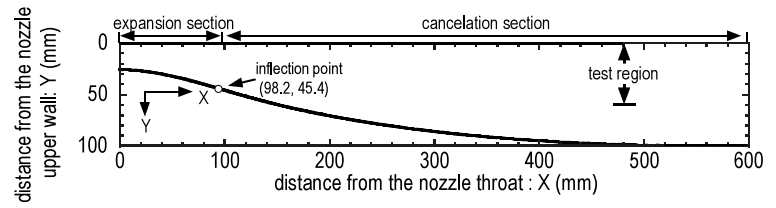

(a) ノズルコンタのプロファイル

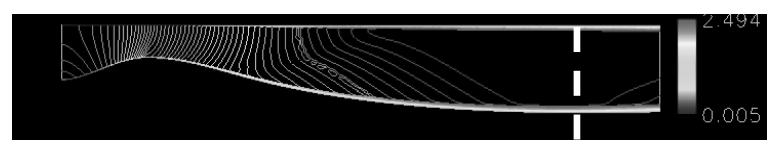

(b) M2.5 時のマッハ数分布

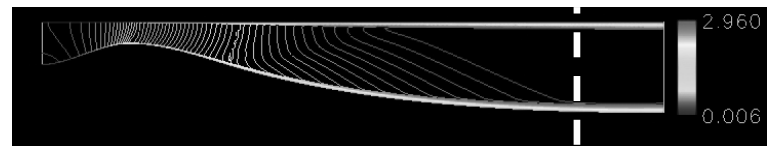

(c) M3.0 時のマッハ数分布

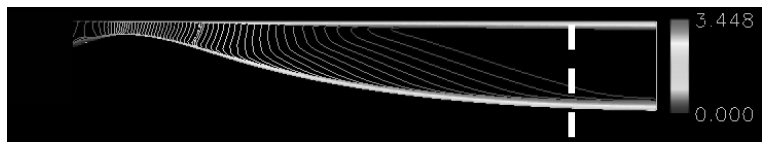

(d) M3.5 時のマッハ数分布

第 2 図 壁面形状と数値計算で求めたマッハ数分布 (破線は出口断面 を示す)

をもちいた . また乱流モデルはメンターの SST 二方程式モ デル8)をもちいた . 格子は構造格子で, 格子点数を 4 万点, 壁面付近の最小格子幅は $1 \mu \mathrm{m}$ とした . また気体は分子量 28.8 , 比熱比 1.4 の熱的完全気体とした .

数值計算では気流総温を $290 \mathrm{~K}$ とした . またノズル総圧 は気流マッハ数が 3.5 のとき $1 \mathrm{MPa}$ とした . ノズル出口で の単位レイノルズ数は $2 \sim 4 \times 10^{7}(1 / \mathrm{m})$ である. 数值計算 は一つの基準コンタに対して，気流マッハ数を $\mathrm{M} 2.5,3.0$ ， 3.5 の 3 通りに変化させておこなった . 弚して通常, 空力 試験に使用するエンジン模型の高さが $50 \mathrm{~mm}$ であること から , ノズル上壁から $60 \mathrm{~mm}$ までのマッハ数分布と気流偏 角を調べた .こうして基準マッハ数, 超音速部や亜音速部 の長さの比率を変化させながら, 特性曲線法と数値計算を 交互に繰り返した．乥して M2.5 から M 3.5 て気流偏角と マッ八数非一樣度の最大值を求め, 光の二つの值が共に最 小となる形状を求めた . 兴の結果，第 2 图 (a) に示すよう な, 超音速部の長さが $600 \mathrm{~mm}$ で出口マッ八数が $\mathrm{M} 2.9$ の とき完全波消しになる形状に決定した .このコンタの初期 膨張部は $100 \mathrm{~mm}$, 相殺部は $500 \mathrm{~mm}$ であり，初期膨張部 の形状は 3 次曲線で近似した .

第 2 図 (b) から (d) に M2.5 から M3.5 までの計算結果 をマッ八数分布で示す. 図中の破線は実際に試験で使用す るノズル出口を示す．壁面付近では境界層が発達している 樣子が見える. 第 2 図 (c) は設計点近くの M 3.0 における 分布である . 流れは左の亜音速部からスロートで凸型の音 速線を経て，初期膨張部で発生する膨張波によって加速さ れる.この初期膨張部で発生した波は, 上壁で反射し相殺 部で打ち消される. 乥して上壁の半ばから，マッハ角を頂 
第 1 表 供試部 $(0<Y<60)$ の中心軸上におけるコアマッハ数の一樣度と境界層厚さ

\begin{tabular}{|c|c|c|c|c|c|c|c|c|c|c|c|}
\hline \multirow[b]{2}{*}{ (a) } & \multicolumn{6}{|c|}{ Numerical result } & \multicolumn{5}{|c|}{ Experimental result } \\
\hline & (b) & (c) & (d) & (e) & (f) & (g) & (h) & (i) & (j) & (k) & (l) \\
\hline$M_{\text {nom }}$ & $M_{\text {ave }}$ & $\Delta M(\%)$ & $\theta(\mathrm{deg})$ & $\delta_{99}(\mathrm{~mm})$ & $\delta_{1}(\mathrm{~mm})$ & $\delta_{2}(\mathrm{~mm})$ & $M_{\text {ave }}$ & $\Delta M(\%)$ & $\delta_{99}(\mathrm{~mm})$ & $\delta_{1}(\mathrm{~mm})$ & $\delta_{2}(\mathrm{~mm})$ \\
\hline 2 & 2.04 & 0.21 & 0.42 & 5.59 & 1.47 & 0.45 & 1.95 & 1.18 & 6.35 & 1.46 & 0.47 \\
\hline 2.5 & 2.48 & 0.35 & 0.53 & 6.96 & 1.88 & 0.47 & 2.48 & 1.49 & 6.72 & 2.01 & 0.49 \\
\hline 3 & 2.95 & 0.3 & 0.48 & 7.45 & 2.28 & 0.43 & 2.99 & 1.17 & 7.44 & 2.61 & 0.49 \\
\hline 3.5 (fixed) & 3.48 & 1.73 & 1.3 & 5.84 & 2.13 & 0.31 & 3.45 & 2.68 & 6.72 & 2.30 & 0.33 \\
\hline 3.5 & 3.44 & 0.79 & 0.65 & 7.64 & 2.82 & 0.42 & 3.49 & 1.47 & 7.89 & 3.04 & 0.44 \\
\hline 4 & 3.94 & 2.85 & 0.98 & 9.13 & 3.40 & 0.41 & 3.94 & 3.39 & 8.82 & 3.81 & 0.44 \\
\hline
\end{tabular}

角にもつ M3.0の一樣流領域が形成されている.

一方，基準となる M2.9より出ロマッハ数を上げる場合 は , マッ八角が小さくなるためにマッハ数が一樣になる領 域か下流側に移動する．光のためノズル出口でも，下壁側 に加速が不十分な領域が生じる．例えば第 2 図 (d) に示し た M 3.5 では下壁面から $30 \mathrm{~mm}$ 程度まで意図したマッハ数 よりも 0.1 程度マッハ数が低い領域ができている.

またマッ八数が 2.9 より低い場合は, 第 2 図 (b) で示す ようにノズル出口付近で下壁より圧縮波が発生し，マッハ 数が若干低い部分ができる．これは下壁コンタを出口端を 中心にして回転させているために，M2.9より下のマッハ 数では開口比が出口より上流で最大になることが原因であ る.例えば $\mathrm{M} 2.5$ では出口よりも $120 \mathrm{~mm}$ 上流で開口比が 最大值 1.72 となり，出口断面で開口比 1.69 まで咸少する 产のため途中でマッハ数が出口よりも大きい部分が存在す る . 相殺部の曲率が大きいほど, この開口比が最大になる 部分が上流に移動し, かつ出口開口比との差も大きくなる. 光こで本研究では超音速部を極力長くし, 相殺部の曲率が 小さくなるようにした .

こうして風洞のスペースが限られた条件下で超音速部を 長くしたため，亜音速部は短くなった，さらに亜音速部の 上流側には整流筒があるため，不連続な断面積変化がある． これら亜音速部の長さや不連続な形状が気流に与える影響 を, 数值計算によって見積もった. 兴の結果, 気流偏角の 増加は 0.1 度, 非一樣度の増加は $0.1 \%$ でり, 亜音速部の 不連続形状の影響は無視できると判断した。

このようにして数值計算によって求めた供試コア部 $(0<$ $Y<60 \mathrm{~mm})$ のマッ八数の非一樣度 $(\%)$ を, 第 1 表の (c) 列に示す . 非一樣度はマッ八数の最大值と最小值の差を平 均マッハ数で割ったもので評価した.上壁から $60 \mathrm{~mm}$ まで の供試コア部のマッハ数は設計範囲の M 2.5 から M 3.5 ま で $0.8 \%$ 以内に保たれていることが分かる. 第 1 表に併記 した既存 M 3.5 固定マッ八数ノズルの計算結果と比較して も，本研究で製作したノズルのマッ八数一樣度は良い.さ らに M4 でも非一樣度は $3 \%$ 以下であり，M3.5 固定ノズル と比較したマッ八数非一樣度の上昇は $1 \%$ 程度と小さい 。

また抗力や空気捕獲率の計測においては，マッハ数の一 樣度と共に気流の偏角も計測精度に影響を及ぼす．乥こで 第 3 図に数值計算から得られたノズル出口での偏角分布を 示す、横軸がノズル上壁からの距離を示し, 縦軸は水平方 向に対する偏角を示す．偏角は時計方向を正とした 。

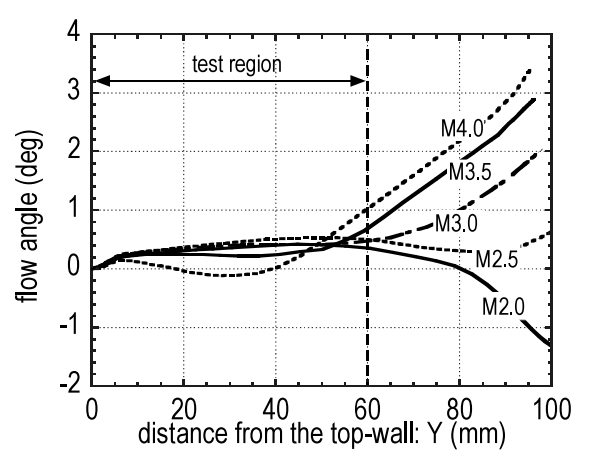

第3 図 CFD から得られたノズル出口の気流偏角 (時計方向が正)

全てのマッ八数において $0<Y<10$ で偏角が 0.3 度増 加している . これは上壁で発達する境界層の排除効果によ るものである.したがってこの偏角増加は, 上壁の形状を 境界層排除厚さの発達にあわせて製作すれば減らすことが できる.しかし実機においても，機体表面に発達する境界 層を取り込んだ場合，エンジン入口で同樣の気流偏角が生 じるため上壁は平板とした .

$10<Y<60 \mathrm{~mm}$ の供試コア内では $\mathrm{M} 4$ 以外では 0.3 度 のままほぼ一定の偏角を保つ．M4 で偏角が減少するのは 他のマッハ数に比ベ, マッ八数が一樣の領域が形成される のが出口に近いためである. M4 では $Y=40 \mathrm{~mm}$ 付近で， 弚れ以外のマッハ数でも $Y=60 \mathrm{~mm}$ 付近で偏角か変化す る.これらは下壁に近づくにつれて , コンタの影響を受け るためである .

第 3 図に示した結果から求めた，供試部内での偏角の絶 対值の最大值を第 1 表の (d) 列にまとめた . 全てのマッハ 数て気流偏角は 1 度以内に収まっている. 既存 M 3.4 固定 マッハ数ノズルの計算結果が 1.3 度であったのと比較する と，今回設計したノズルの性能は良好である.

2.3 ノズルの製作 数值計算によって得られた結果を 元にしてノズルを製作した.製作に当たって，出口断面や 全長を既存の風洞ノズルにあわせ，風洞試験部の改修を最 小限にとどめるようにした .さらに M4 試験までは加熱空 気を使う必要がないことから，交換作業が容易になるよう に材質には一部を除き軽量なジュラルミン (YH75, 比重 2.8 , ヤング率 $71500 \mathrm{~N} / \mathrm{mm}^{2}$ ) をもちいた .

下壁の肉厚は, 数値計算によって得られた壁圧分布を元 にたわみ量を見積もった結果， $25 \mathrm{~mm}$ とした．下壁はワイ ヤカットによって製作した . 製作後, 加工精度を実測したが 
誤差は $0.2 \mathrm{~mm}$ 以下であった . $25 \mathrm{~mm}$ の肉厚でも風洞通風 中に下壁コンタがたわまないように，下壁の裏側にかかる 圧力を試験室圧力と等しくなるようにし，裏と表での差圧 をなるべく小さくした · また差圧を小さくしたことによっ て，下壁と側板との間の気密も $\mathrm{O}$ リングのみでおこなうこ とができた .この $\mathrm{O}$ リングによる気密は , ノズル内壁面の オイルフローや壁圧分布によって確認した .

\section{3.ノズル較正実験}

3.1 較正実験のシーケンス 前章のようにして設計・製 作したノズルの較正試験をおこなった . 第 4 図に気流マッ 八数を実験中に 4 から 2 を経由して 4 に戻したときの，風 洞各部の圧力および気流マッハ数の時間変化の一例を示す 図の左軸に圧力を示した . 図の右軸はノズル出口のマッハ 数で, 総圧とノズル上壁の出口壁圧から計算したものであ る.この実験では M4 から M2 までを㫕れ光れ 15 秒で往 復させている .マッハ数の変化速度は, 油圧制御機内の絞 り弁によって自由に設定でき,さらに遠隔操作により途中 で一時停止もできる .

計測開始から 3 秒 $(t=3 \mathrm{~s})$ でエジェクタが起動し, 図中 で最上段に示したエジェクタ駆動圧が急上昇している．エ ジェクタ駆動圧は $t=7 \mathrm{~s}$ で定常になり， $3 \mathrm{MPa}$ を示してい

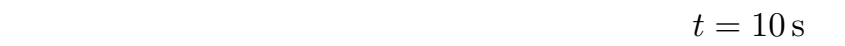
ノズル上流側の仕切り弁を開き，気流を発生させる．ノズ ル総圧は計測開始から $t=20 \mathrm{~s}$ 付近で $700 \mathrm{kPa}$ の定常値を 示す .このとき試験室圧とノズル出口圧は等しくなり，ノ ズル気流は M4 の適正膨張になっている .

$t=22 \mathrm{~s}$ において, 気流マッハ数を下げるためにノズルス ロートを拡大させた . スロートの拡大によってノズル総圧 は $0.6 \mathrm{MPa}$ から $0.08 \mathrm{MPa}$ まで低下する .この総圧の低下 は, 風洞運転中ノズル上流側の仕切り弁の開度を固定して, ノズルに供給する質量流量を一定にしているためである．

$t=50 \mathrm{~s}$ 付近からノズルスロートを縮小し, マッハ数を上 げた .再度 M4 になったときにはノズル総圧は $0.5 \mathrm{MPa}$ まで 上昇している．マッハ数変化の最初と最後て総圧が $0.6 \mathrm{MPa}$ から $0.5 \mathrm{MPa}$ に低下したのは気蓄器圧の低下によるもので ある . ノズル出口圧は最初の $\mathrm{M} 4$ 時には $4.5 \mathrm{kPa}, \mathrm{M} 2$ 時に

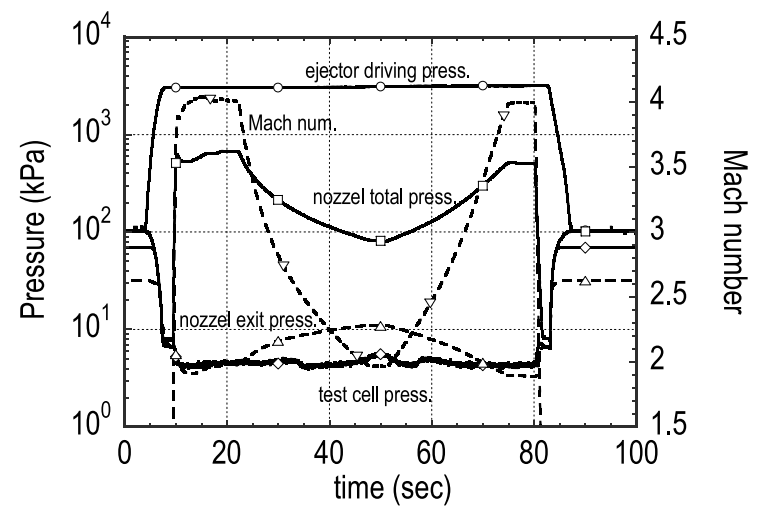

第 4 図 較正実験での圧力および気流マッハ数の時間履歴
$11 \mathrm{kPa}$ まで上昇し，再び $\mathrm{M} 4$ になったときには $3.2 \mathrm{kPa}$ ま で咸少する.一方, 試験室圧は $4.5 \sim 5.5 \mathrm{kPa}$ を保持してお り，風洞運転中ほとんどの領域でノズル流は不足膨張になっ ている. 炎のためノズル出口端面から膨張波は発生するが， 斜め衝撃波は発生しない．また膨張波についても，2.1 節 で述べたようにノズル下壁を長くしているため, エンジン 内部には入射しない．

3.2 ノズル出ロのマッハ数分布と境界層厚さ 第 5 図 にピトー管で測定したノズル上壁出口断面 (スロートから $480 \mathrm{~mm}$ の位置) の中心線上における高さ方向のマッハ数分 布を示す . 横軸はノズル上壁からの距離 $(Y)$, 縦軸はマッ 八数である . 図の横軸は, 境界層内のマッハ数分布を強調 するために対数プロットしている．数値計算の結果を実線 や破線で，また実験結果を点で示した．実験点には，境界 層内については静圧を近傍の壁圧で代表させて求めたもの を, コア内についてはピトー圧と総圧の比から求めたもの

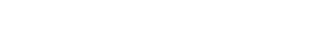

数值計算の結果と実験値はコア流と境界層内ともに良く 一致している . 数值計算では乱流モデルにメンターの SST 二方程式モデルを使用したが, 第 5 図の結果から本研究で 使用した乱流モデルが妥当であったことが分かる.供試コア 内のマッハ数分布は M2 から M3.5 まで一定になっている . $\mathrm{M} 4$ では $Y=50 \mathrm{~mm}$ 以上でマッハ数が減少してくる .これ は第 2 図 $(\mathrm{d})$ で示したような, 加速の不十分な領域が下壁 付近に残るためである．同樣のマッハ数測定を，ピト一管 をノズルの幅方向に動かしておこなった . 光して幅 $60 \mathrm{~mm}$ の供試部内での流れの二次元性を確認した .

第 5 図で示した結果から求めた各マッハ数における $99 \%$ 速 度厚さ, 排除厚さ, 運動量厚さ, コア部のマッハ数の非一樣 度を第 1 表にまとめた . 数値計算によって設計時に予測し た各種境界層厚さは，実験值とよく一致している．99\%速 度厚さは M4 のとき最大で， $8.8 \mathrm{~mm}$ であった．したがっ てエンジンの空力試験をおこなう際に，模型を高さ方向に $10 \mathrm{~mm}$ 動かすことによって，ノズル境界層流入の影響を調 ベることができる .

また供試部の一樣度は数値計算の結果に比べ低下するも のの, M4 でも最大で $3.5 \%$, M 3.5 から M2 では $1.5 \%$ 以下 と良好である . 既存 M3.5 固定マッハ数ノズルと比較した

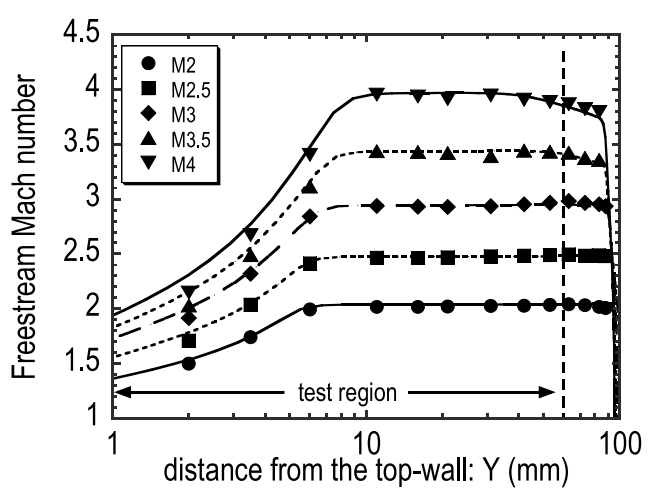

第 5 図 ノズル出口でのマッハ数分布 
場合，M4 以外では $1 \%$ 以上一樣度は良く, M4 亿゙も $0.7 \%$ の 低下で収まっている.このように本研究で製作したノズル では, 既存ノズルに比べて一樣度か改善された 。

\section{4. スクラムジェットエンジンの空力試験}

4.1 実験装置 固定形状インレットをもつ超音速エン ジンでは, 低マッハ数時にインレットが不始動になりやす い，一旦インレットが不始動になると，スピル流量か増大 して付加抗力か増すだけでなく, 燃焼器に十分な空気流量 を供給できない，乥こで新しい可変マッハ数ノズルをもち いてスクラムジェットェンジンの空力試験をおこない , 抗 力と捕獲率の変化を調べた . 実験中に主流マッ八数を 2 ～ 4 ,

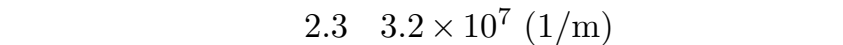
変化させた . 最初に空力試験にもちいた実験装置を示す .

4.1.1 エンジン模型 第 6 図に実験にもちいたスクラム ジェットエンジンの模型9) を示す .この模型は 2 枚の側板 ， 下方のカウル, 上方の天板からなる矩形断面の側板圧縮型工 ンジンである.エンジンはインレット, 分離部, 燃焼器, ノ ズルの 4 つに分けることができる.内部流路はインレット入 口とノズル出口が同寸法になっており，模型全長は $440 \mathrm{~mm}$ ， 高さは $50 \mathrm{~mm}$, 幅は $40 \mathrm{~mm}$ である .

インレットの幾何学的収縮比は 2.8 である .このインレッ 卜側壁の前縁部は半頂角 6 度のくさびになっており，これ により空気を圧縮する . 前縁には 45 度の後退角がついて おり，この後退角によって圧縮の過程で空気は下向きに曲 げられ，スピルする．インレットで圧縮された空気は分離 部, 燃焼器を通って, 拡大部で推力を発生する。

エンジン模型の内部には，流れ場を調べるために 150 点 の壁圧孔を設けた . また模型にかかる抗力を計測するため に，模型を力計測装置 (FMS) を介して試験室内に取り付 けた . FMS のメカニズムについては文献 10) に詳しく記 述されているので光ちらを参照されたい．本研究ではこの FMS によって模型にかかる抗力を計測した .

4.1 .220 点ピトー静圧レイク 第 7 図に空気捕獲率を 計測するのに使用した 20 点ピトー静圧レイクを示す.こ のピトー静圧管は高さ方向に $10 \mathrm{~mm}$ 間隔で 5 本ずつ, 幅 方向に $9 \mathrm{~mm}$ 間隔で 4 本ずつ, 計 20 本のピト一静圧管を 並べたものである.当初, 5 本 $\times 5$ 本の 25 点ピト一静圧レ イク ${ }^{11)}$ を取り付けたが, レイク間の幅が $8 \mathrm{~mm}$ と狭いため に, 主流マッ八数が低くなると衝撃波がレイク間のスロー

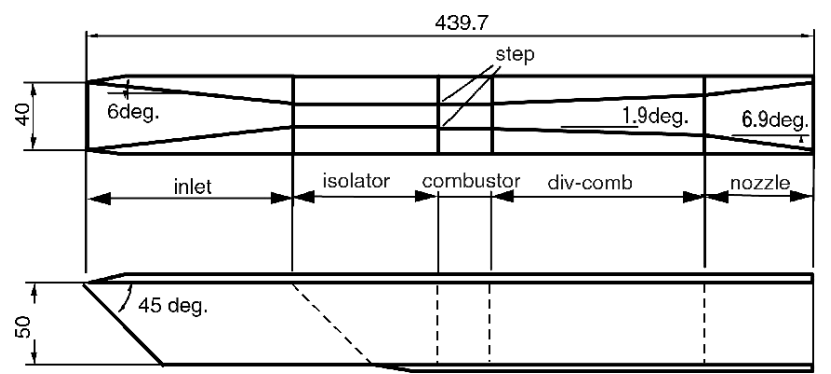

第6 図 各種模型 (単位 : mm)
卜部を通過することができず圧力計測に影響を与えた．乥 こで 25 点レイクを改修し, 幅方向のピト一管を 4 本に減 らし間隔を $9 \mathrm{~mm}$ とした . 各ピトー静圧管の長さは $17 \mathrm{~mm}$ で, 静圧孔は先端での衝撃波の影響を減らすために，先端 から $7 \mathrm{~mm}$ (直径の 6 倍) の位置に設けた. 静圧孔は流れ の偏角の影響を除去するために 90 度間隔で 4 個設け, 光 れらの平均值を計測するようにしている .

このピトー静圧レイクを, トラバーサを介してエンジン 出口に取り付けた . 一通風中に気流マッハ数を変化させる 場合は，レイクを固定し 20 点の圧力計測の結果から空気捕 獲率を求めた . ただし 20 点の計測では境界層内部の測定 点数が不十分なために，空気捕獲率を過小評価する．この 境界層の影響は，圧力計測を 150 点以上おこなえば無視で きることが著者らによって示されている ${ }^{12)}$. 艺こでより精 度の高い空気捕獲率を測る場合には, 気流マッ八数を固定 し，レイクを試験中に動かすことによって 150 点の圧力計 測をおこなった . 各ピトー静圧管はエンジン内部に $7 \mathrm{~mm}$ 挿入し，静圧孔とエンジン出口端面を一致させた .なお，ピ トー静圧管挿入による出口断面の閉塞率は $3 \%$ 以下であり， 模型の始動性に与える影響は無視できる .

4.2 気流マッハ数変化時のエンジン内部流の変化 気 流マッハ数か変化したときのエンジン内部流の変化を調べ るために壁圧測定をおこなった . 第 8 図に気流マッハ数を M3.5 から M2.0 まて変化させたときの, 模型の側壁壁圧分 布を示す.壁圧は気流動圧 $q_{1}$ で無次元化した形で示してい る . 図中の黑点は壁圧孔の位置を，○は壁圧が最大の箇所 を, メは最小の箇所を光れ光れ示す。

M3.5 ではインレット先端で生じた衝撃波がインレット 内で反射を繰り返し，インレット出口で $0.6 q_{1}$ まで圧力を 上昇させている .このときインレット先端の後退角によっ て，衝撃波を通過するたびに気流は下向きに曲げられてい く. 兴の下向き角をもった流れがカウル先端に当たること によって強い衝撃波が生じ，カウル付近で $0.7 q_{1}$ 以上の高 圧域が生じている．また著者らによって，上流境界層流入 時には側板前縁からの衝撃波との干渉によって天板上の境 界層が剝離することが示されている11)。

M3.0では圧力の最大值がインレット出口付近に移動し， 分離部の圧力が咸少している.これはマッ八数の減少によっ

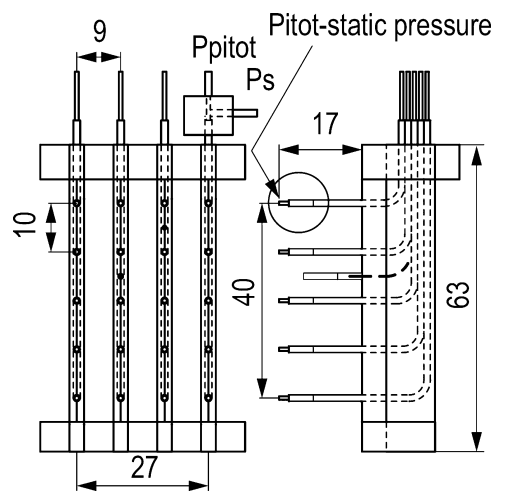

第 7 図 20 点ピトー静圧レイク (25 点レイクを改修) 
(a) M3.5

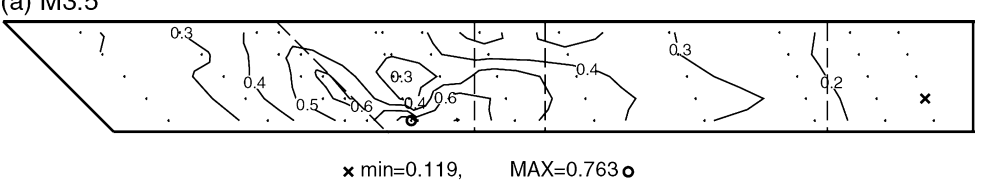

(b) M3.0

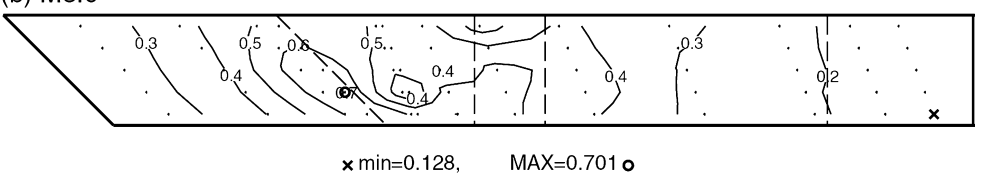

(c) M2.5

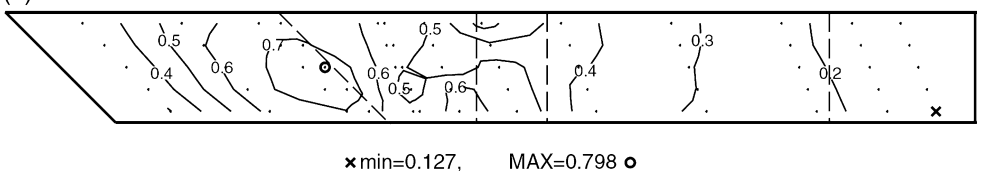

(d) M2.0

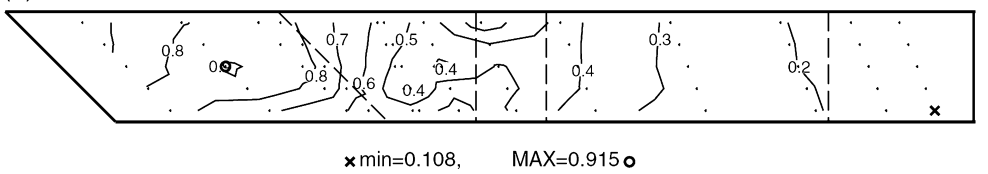

第8图 インレット不始動に移行するときの壁圧分布の変化 (ノズル境界層流入 時, $Y=0)$

て側板衝撃波の反射回数か増加し, 天板境界層がより上流 で剥離したためである.この衝撃波によってインレット出 口で流れは下向きに曲げられスピル流量が増加する．また この衝撃波によってマッ八数が減少するために, カウル衝 撃波か弱まり分離部内の圧力が減少している.M2.5 では, 彔離による衝撃波がより上流で起こるようになり，0.7q 高圧領域がインレット出口付近から上流側に向けて広がっ ている.さらにマッ八数か下がって M 2.0 ではインレット中 心付近に $0.9 q_{1}$ の高圧領域がみえ，インレットは不始動に なっている．インレット内は逆圧勾配だが，剝離が瞬間的 に入口まで遡ることは観察されなかった．また剝離によっ てスピル流量が増加するために , 拡大部の壁圧分布はほぼ 一定である.気流マッ八数の減少に伴い, 剝離が徐々に上 流に移動していくことによって不始動に移行した．

インレット不始動に移行する過程での空気捕獲率を調べ るために, エンジン出口に 20 点ピトー静圧レイクを取り 付け，空気捕獲率を計測した . 第 9 图にノズル境界層がエ ンジン内に流入しないように模型をコア側に $10 \mathrm{~mm}$ 移動 して固定し, 気流マッハ数を変化させたときの空気捕獲率 の変化を示す.気流マッハ数を一通風中に変化させ , 固定 したプローブレイクによる 20 点の圧力計測から求めた空 気捕獲率を線で示した、気流マッハ数が $\mathrm{M} 2$ から $\mathrm{M} 4$ へ増 加したときの捕獲率を実線で，M4 から M2 に減少したと きの值を破線で示した．さらに気流マッ八数を固定しレイ クをトラバースすることによって 150 点の圧力計測をおこ なった．弚の結果から求めた捕獲率を実験点で示す.

境界層内の測定点数が不足しているため, 詳細測定に比 ベてレイクを固定した場合の方が小さい值を示している

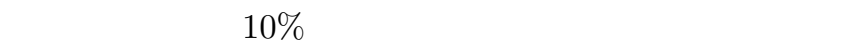
る.したがって境界層か計測結果に及ぼす影響はマッ八数

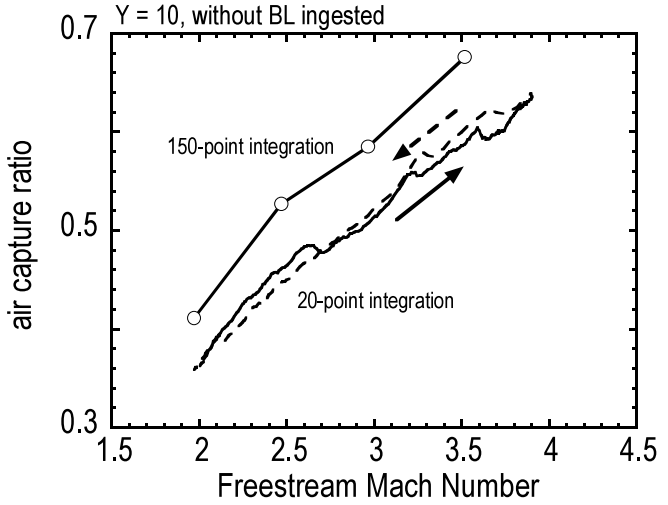

第 9 図 気流マッハ数変化時の空気捕獲率の変化 $(Y=10)$

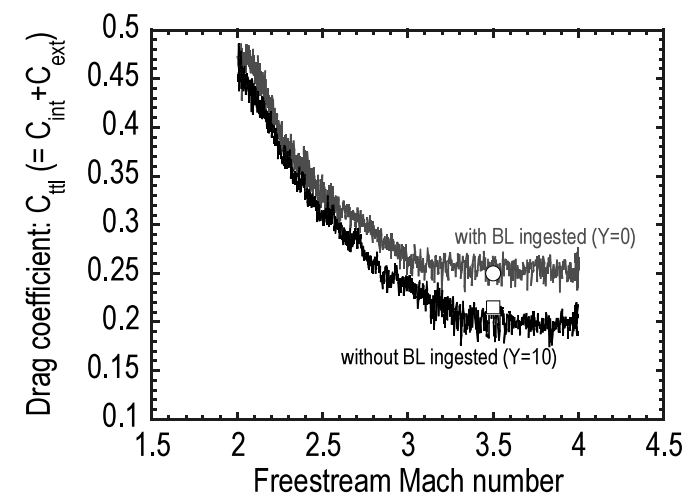

第 10 図 気流マッハ数が変化したときの抗力の変化 (実験 点は既存 M3.5 固定マッハ数ノズルによる結果 ${ }^{14)}$ )

に依存せず，20 点の計測から捕獲率の変化の樣子を調べる ことができる .

壁圧測定ではマッハ数の減少に伴いインレットは不始動 になったが, 捕獲率の急変化や, マッハ数変化によるヒス テリシスはない， 兴のため不始動点を明確に定義できない . 以上のことから本研究で観測された不始動は, スロート部 から垂直衝撃波を吐き出す強不始動 (hard unstart) では なく，インレット内部での境界層剝離による弱不始動（soft unstart) である ${ }^{13)}$.このように側板圧縮型ではマッハ数の 低下によって衝撃波の反射回数か増加し，インレット内で 境界層を剝離させる．弚の結果インレットは弱不始動にな る.これを防ぐには側板前縁のくさび角を小さくして衝撃 波角を減らし，代わりにランプ圧縮などを組み合わせる必 要がある.

4.3 インレット 不始動に伴うエンジン抗力の増加 イン レット弱不始動に伴うエンジン抗力の变化を調べた .第 10 図 の絴軸は,FMS の指示值をエンジン入口断面積と気流動圧で 無次元化したエンジン全体の抗力係数 $\left(C_{\mathrm{ttl}}=C_{\mathrm{int}}+C_{\mathrm{ext}}\right)$ で , 横軸は気流マッハ数である . 图の M 3.5 における実験 点は既存の固定コンタノズルによるデータ ${ }^{14)}$ で , 今回の可 変マッ八数ノズルによる抗力值は実線で示されている. 図 中, 上側の線は $Y=0$,もう 1 本の線は $Y=10 \mathrm{~mm}$ に光 れ光れ固定したときの結果を示す． $Y=0,10 \mathrm{~mm}$ 共に可 
変マッハ数ノズルによる実験結果は, 既存固定コンタノズ ルの結果と一致している．

全体的に $Y=10 \mathrm{~mm}$ の方が $Y=0$ に比べて抗力が小 さい.これは $Y=0$ の場合ノズル境界層がエンジン内に流 入しているため, 天板上の境界層が厚くなり， $Y=10 \mathrm{~mm}$ に比ベてインレットの上流で剥離しているためである . 境 界層が剝離すると衝撃波が生じ, 剝離のない場合よりイン レット壁面の圧力を上昇させ抗力を増大させる．

$Y=0$ では $\mathrm{M} 3$ 以上 , $Y=10 \mathrm{~mm}$ では $\mathrm{M} 3.3$ 以上では $C_{\mathrm{ttl}}$ はほぼ一定値を保っており，主流マッハ数が 6.7 までほ とんど変化しないことも確認されている ${ }^{10)}$. 一方, マッハ 数が光れ以下に下がると, 抗力は単調に増加する. この抗 力の増加は, 壁圧分布でも示されているように境界層剝離 が上流に移動するためである、剝離により衝撃波が生じイ ンレットでの抗力面の圧力が上昇する．またこの衝撃波に よって捕獲率が咸少するために拡大部での圧力が減少し, 結 果として抗力か増加する.結果として， $Y=0$ では M 3 か ら $\mathrm{M} 2$ の間に 0.25 から 0.48 まで, $Y=10 \mathrm{~mm}$ では M 3.3 から M 2 までに 0.22 から 0.47 までいずれも抗力が 2 倍程 度増加している。

$$
\text { 5. ま と め }
$$

M2 から M4 まで気流マッハ数を通風中に変化できる可 変マッ八数ノズルを設計・製作した .このノズルをもちい て側板圧縮型スクラムジェットエンジンの空力試験をおこ なった .これらの結果から以下の知見を得た .

1. CFD をもちいて, マッ八数一樣度と気流偏角につい てノズル形状の最適化をおこなった．CFDによるノズル 出口の供試部のマッハ数一樣度は $2.9 \%$ 以内, 気流偏角は 1 度以内である。

2. このノズルのコアマッハ数の一樣度を測定した . $10<$ $Y<60 \mathrm{~mm}$ の供試コア内では $\mathrm{M} 2$ から $\mathrm{M} 3.5$ では $1 \%$ 以 内 , M4 まで含めても $3.4 \%$ 以内であった .これはエンジン 空力試験にもちいるには十分である .

3. このノズルをもちいて, 気流マッ八数变化時の外部圧 縮型インレットの始動・不始動について調べた . 気流マッ 八数の減少によって境界層剝離が徐々に上流に移動し, イ ンレットは弱不始動に移行していく.

4. 弱不始動になっても空気捕獲率の急減少は起こらな い. しかし弱不始動になると抗力面での圧力が上昇するた め, エンジン抗力は増加する .

実験を進めるにあたり，中国科学院力学研究所の陳立紅 助教授に支援をいただいた . また本研究は, 文部科学省 21 世紀 COE プログラム「流動ダイナミクス国際研究教育拠 点」の支援を受けた .ここに記して謝意を表す．
記号 表

$C_{\mathrm{ext}}:$ エンジン外部抗力の抗力係数

$C_{\mathrm{int}}:$ エンジン内部抗力の抗力係数

$C_{\mathrm{ttl}}:$ エンジン模型全体の抗力係数 $\left(C_{\mathrm{int}}+C_{\mathrm{ext}}\right)$

$M_{\mathrm{ave}}$ : 供試コア内の平均マッハ数

$M_{\text {nom }}:$ 公称マッハ数

$\Delta M:$ 供試コア内のマッ八数の非一樣度 $(\%)$

$q_{1}:$ 主流動圧

$R e:$ 主流単位レイノルズ数

$Y:$ ノズル上壁からの鉛直方向距離

$\delta_{99}: 99 \%$ 境界層厚さ

$\delta_{1}:$ 境界層排除厚さ

$\delta_{2}:$ 境界層運動量厚さ

$\theta:$ 供試コア内の気流偏角の最大値

\section{参 考 文 献}

1) 三谷 徹, 富岡定毅, 荻田丈士, 谷香一郎, 鎮西信夫, 河内俊憲： RJTF 試験における性能達成度, 日本航空宇宙学会論文集, 52 (2004), pp. 1-9.

2) 空気力学部: $1 \mathrm{~m} \times 1 \mathrm{~m}$ 吹き出し式超音速風洞の計画と構造，航 空宇宙技術研究所報告 TR29，1962.

3) 関根英夫, 野田順一, 渡辺光則 : 航技研 $1 \mathrm{~m} \times 1 \mathrm{~m}$ 超音速風洞 のノズル改修後の気流特性, 航空宇宙技術研究所資料 TM-694, 1996.

4) Rope, A. and Goin, K.: High-Speed Wind Tunnel Testing, Robert E. Krieger Publishing Company, New York, 1978, pp. 107-108.

5) Kanda, K. and Kudo, K.: Conceptual Study of a Combined Cycle Engine for an Aerospace Plane, J. Propul. Power, 19 (2003), pp. 297-301.

6) Riise, H. N.: Flexible-Plate Nozzle Design for TwoDimensional Supersonic Wind Tunnels, J. P. L. Rept-20-74, California Institute of Technology, 1954.

7) Wada, Y. and Liou, M.-S.: A Flux Splitting with HighResolution and Robustness for Discontinuities, AIAA Paper 94-0083, 1994

8) Menter, F. R.: Two-Equation Eddy-Viscosity Turbulence Models for Engineering Applications, AIAA J., 32 (1994), pp. $1598-1605$.

9) 三谷 徹, 他: 小型風洞とエンジン補完実験, 航空宇宙技術研究 所報告 TR-1458，2003。

10）樽川雄一, 三谷 徹, 平岩徹夫, 升谷五郎 : スクラムジェットエ ンジンの 3 分力測定 1) マッハ 4 から 8 飛行条件におけるエン ジン抗力, 日本航空宇宙学会論文集， 51 (2003), pp. 244-251.

11) 北村英二郎, 三谷 徹, 櫻中 登, 泉川宗男, 渡邊修一, 升谷五 郎 : 多点ピト一静圧測定によるスクラムジェットインレットの空 気捕獲率計測，日本航空宇宙学会論文集 , 53 (2005), pp. 22-28.

12) Kitamura, E., Mitani, T., Sakuranaka, N., Izumikawa, M. and Masuya, G.: Measuring the Aerodynamic Performance of Scramjet Engines by Multi-Probe-Rakes, International Symposium on Space Technology and Science, 2004 a-7, 2004.

13) Van Wie, D. M., Kwok, F. T. and Walsh, R. F.: Starting Characteristics of Supersonic Inlets, AIAA-96-2914, 1996.

14) 三谷 徹, 樽川雄一, 泉川宗男, 渡邊修一, 志村 隆 : スクラム ジェットェンジンの 3 分力測定 2) 外部流と境界層吸い込みの 影響, 日本航空宇宙学会論文集, 51 (2003), pp. 252-259. 